\title{
Winter Annual Weed Response to Nitrogen Sources and Application Timings prior to a Burndown Corn Herbicide
}

\author{
Kelly A. Nelson \\ Division of Plant Science, University of Missouri Lee Greenley Jr. Memorial Research Center, Novelty, MO 63460, USA \\ Correspondence should be addressed to Kelly A. Nelson; nelsonke@missouri.edu
}

Received 8 September 2015; Accepted 17 November 2015

Academic Editor: Ravindra N. Chibbar

Copyright ( 2015 Kelly A. Nelson. This is an open access article distributed under the Creative Commons Attribution License, which permits unrestricted use, distribution, and reproduction in any medium, provided the original work is properly cited.

\begin{abstract}
Autumn and early preplant $\mathrm{N}$ applications, sources, and placement may affect winter annual weed growth. Field research evaluated (1) the effect of different nitrogen sources in autumn and early preplant on total winter annual weed growth (2006-2010), and (2) strip-till and broadcast no-till N applied in autumn and early preplant on henbit (Lamium amplexicaule L.) growth (20082010) prior to a burndown herbicide application. Total winter annual weed biomass was greater than the nontreated control when applying certain $\mathrm{N}$ sources in autumn or early preplant for no-till corn. Anhydrous ammonia had the lowest average weed density $\left(95\right.$ weeds $\left.\mathrm{m}^{-2}\right)$, though results were inconsistent over the years. Winter annual weed biomass was lowest $\left(43 \mathrm{~g} \mathrm{~m}^{-2}\right)$ when applying $32 \%$ urea ammonium nitrate in autumn and was similar to applying anhydrous ammonia in autumn or early preplant and the nontreated control. Henbit biomass was $28 \%$ greater when applying $\mathrm{N}$ in the autumn compared to an early preplant application timing. Nitrogen placement along with associated tillage with strip-till placement was important in reducing henbit biomass. Nitrogen source selection, application timing, and placement affected the impact of $\mathrm{N}$ on winter annual weed growth and should be considered when recommending a burndown herbicide application timing.
\end{abstract}

\section{Introduction}

Winter annual weeds commonly grow in no-till corn and soybean production fields [1-4]. Soils with winter annual weeds may remain cooler at planting time and reduce yields $[3,4]$. Winter annual weeds compete for water, light, and nutrients such as nitrogen [4-9]. The timing of a burndown herbicide for winter annual weed control was important to avoid yield reductions with broadcast urea at $\mathrm{N}$ rates less than $135 \mathrm{~kg} \mathrm{~N} \mathrm{ha}^{-1}$ [4]. Winter annual weed emergence, growth, maturity, and seed production may vary depending on species, soil temperature, and growing degree days [1012], burndown herbicide application timing $[4,10]$, and $\mathrm{N}$ management strategies [4].

Farmers commonly apply $\mathrm{N}$ to claypan soils in autumn or prior to planting due to time constraints and to allow timely corn planting. Yield differences among $\mathrm{N}$ sources for no-till corn [13] have been affected by application timing and rate, while for a reduced-till system limited differences among sources were observed [14]. In claypan soils, greater gaseous $\mathrm{N}$ loss occurred when $\mathrm{N}$ was surface applied in claypan soils compared to subsurface placement, and in some instances gaseous $\mathrm{N}$ loss was reduced when using enhanced efficiency $\mathrm{N}$ treatments [15]. Differences in weed growth to $\mathrm{N}$ management have been reported $[5,6,16-21]$ which could affect the critical period for weed control in corn [22, 23] and the efficacy of burndown herbicides such as glyphosate [8]. Nitrogen source, placement, and timing have affected weed growth and development $[6,16,24]$. After four years of research, $\mathrm{N}$ placement affected weed growth and up to a $63 \%$ reduction in the weed seedbank was observed $[6,24]$. So, it is possible that differences in the $\mathrm{N}$ availability from slowrelease products such as polymer-coated urea as well as $\mathrm{N}$ placement could affect winter annual weed growth compared to readily available $\mathrm{N}$ sources.

Although research has evaluated interactions between cover crops and $\mathrm{N}$ availability [25-27], few studies have evaluated effects of $\mathrm{N}$ on winter annual weed growth prior to planting an annual crop such as corn. Mueller et al. [4] evaluated corn and winter annual weed response to five rates of urea $\left(0-135 \mathrm{~kg} \mathrm{~N} \mathrm{ha}^{-1}\right)$ applied usually as a topdress application timing, but no known research has evaluated the effect 
TABLE 1: Soil test values, nitrogen fertilizer application dates, and weed harvest dates prior to a burndown herbicide application for objectives 1 and 2.

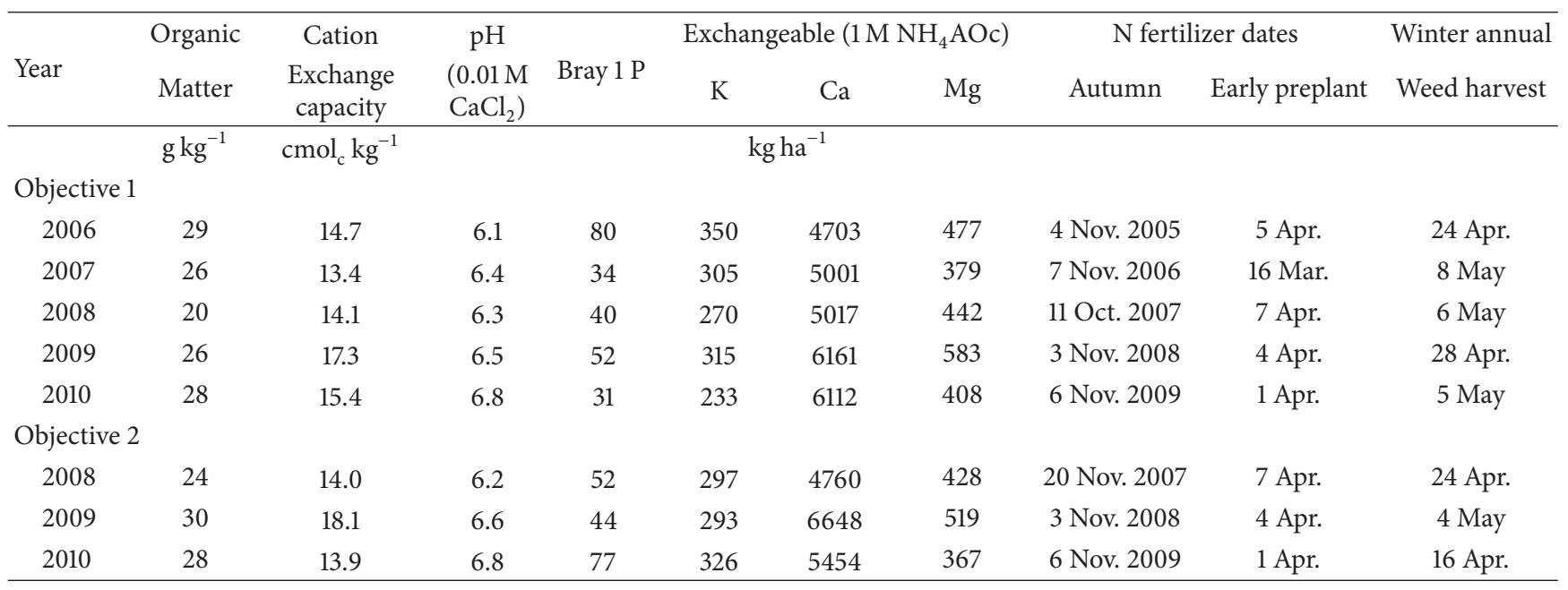

of $\mathrm{N}$ fertilizer placement, $\mathrm{N}$ sources, or $\mathrm{N}$ application timings (autumn or early preplant) on winter annual weed growth prior to a burndown herbicide. The objectives of this study were to (1) evaluate the effect of nitrogen sources applied in autumn and early preplant for no-till corn on winter annual weed growth prior to a burndown herbicide application and (2) evaluate strip-till and broadcast no-till $\mathrm{N}$ applied in autumn and early preplant on henbit (Lamium amplexicaule L.) growth prior to a burndown herbicide application.

\section{Materials and Methods}

2.1. Nitrogen Sources and Application Timings. Field research occurred from 2006 to 2010 at the University of Missouri Lee Greenley Jr. Memorial Research Center near Novelty, Missouri $\left(40^{\circ} 01^{\prime} \mathrm{N}, 92^{\circ} 11^{\prime} \mathrm{W}\right)$ on a Putnam silt loam (fine, smectitic, mesic Aeric Vertic Epiaqualfs). The experiment was arranged as a factorial randomized complete block design with four replications in experimental plots measuring 3 by $15 \mathrm{~m}$. The first factor was $\mathrm{N}$ application timing (autumn and early preplant, Table 1), and the second factor was $\mathrm{N}$ source (nonfertilized control, 32\% urea ammonium nitrate (UAN), ammonium nitrate, anhydrous ammonia, polymer-coated urea, urea plus NBPT (N-(n-butyl) thiophosphoric triamide, Koch Agronomic Services, LLC, Wichita, KS) at $1 \mathrm{~mL} \mathrm{~kg}^{-1} \mathrm{~N}$, and noncoated urea) applied at $168 \mathrm{~kg} \mathrm{Nha}^{-1}$. This rate of applied $\mathrm{N}$ is typical for the region. All $\mathrm{N}$ treatments were broadcast surface applied for no-till except for anhydrous ammonia, which was injected $15 \mathrm{~cm}$ below the soil surface using a no-till coulter, mole knife (Yetter Manufacturing, Inc., Colchester, Illinois), and double-disk closing wheels with minimal soil disturbance. Monthly precipitation and average air temperature are reported in Table 2. A biomass harvest of individual winter annual weeds from two 38 by $76 \mathrm{~cm}$ quadrats was collected and weed densities were determined in the spring prior to a burndown herbicide application each year (Table 1). Samples were dried and total winter annual dry weights were determined.
2.2. Strip-Tillage, $N$ Application Timing, and N Source. This experiment was arranged as a factorial randomized complete block design with three replications in experimental plots that were 3 by $23 \mathrm{~m}$. The first factor was $\mathrm{N}$ application timing (autumn and early preplant, Table 1), and the second was placement and $\mathrm{N}$ source (anhydrous ammonia in the presence or absence of nitrapyrin (2-chloro-6(trichloromethyl) pyridine) (Dow AgroSciences, Indianapolis, Indiana), polymer-coated urea (ESN, Agrium, Calgary, Alberta), urea, or nontreated control) at $140 \mathrm{~kg} \mathrm{Nha}^{-1}$, and placement. The nontreated control, polymer-coated urea, and urea either were broadcast surface applied or included a striptill placement. The $\mathrm{N}$ rate was reduced from $168 \mathrm{Kg} \mathrm{N} \mathrm{ha}^{-1}$ to determine possible differences between enhanced efficiency fertilizers. Strip-tillage $(30.5 \mathrm{~cm}$ width, $20 \mathrm{~cm}$ depth, and $76.2 \mathrm{~cm}$ spacing) was conducted with a 2984 Maverick unit (Yetter Manufacturing, Inc., Colchester, Illinois). Dry N fertilizers (PCU or noncoated urea) were banded to a depth of $15 \mathrm{~cm}$ below the planted row, and fertilizer was delivered using a Gandy Orbit-Air (Gandy Company, Owatonna, Minnesota) ground-driven metering system. Anhydrous ammonia was applied with a no-till coulter, mole knife, and doubledisk closing wheels with minimal soil disturbance. Fertilizer application timings are reported in Table 1 . The primary weed species was henbit, one of the most problematic winter annuals in the Midwestern US, with a weed density of 340 plants $\mathrm{m}^{-2}$ in 2008,180 plants $\mathrm{m}^{-2}$ in 2009, and 120 plants $\mathrm{m}^{-2}$ in 2010. Henbit was hand-harvested from two 38 by $76 \mathrm{~cm}$ quadrats randomly placed in each plot prior to a burndown herbicide application (Table 1). Samples were dried and weights were determined.

2.3. Data Analysis. An analysis of variance was conducted using PROC GLM [28]. Means were separated using Fisher's Protected LSD at $P=0.1$ or 0.05 . Data were combined over years in the absence of a significant interaction between factors and years. For objective 1, individual weed species were analyzed, but the most consistent conclusions arose 
TABLE 2: Mean monthly air temperature and total monthly precipitation at Novelty from 2006 to 2010, and 10-year average (2001 to 2010).

\begin{tabular}{|c|c|c|c|c|c|c|c|c|c|c|c|c|}
\hline \multirow[b]{2}{*}{ Month } & \multicolumn{6}{|c|}{ Air temperature } & \multicolumn{6}{|c|}{ Precipitation } \\
\hline & $\begin{array}{l}2005- \\
2006\end{array}$ & $\begin{array}{c}2006- \\
2007\end{array}$ & $\begin{array}{l}2007- \\
2008\end{array}$ & $\begin{array}{l}2008- \\
2009\end{array}$ & $\begin{array}{c}2009- \\
2010\end{array}$ & $\begin{array}{c}10 \text {-yr } \\
\text { average }\end{array}$ & $\begin{array}{l}2005- \\
2006\end{array}$ & $\begin{array}{l}2006- \\
2007\end{array}$ & $\begin{array}{l}2007- \\
2008\end{array}$ & $\begin{array}{l}2008- \\
2009\end{array}$ & $\begin{array}{c}2009- \\
2010\end{array}$ & 10 -yr average \\
\hline & \multicolumn{6}{|c|}{${ }^{\circ} \mathrm{C}$} & \multicolumn{6}{|c|}{$\mathrm{mm}$} \\
\hline Oct. & 12.6 & 10.4 & 14.4 & 12.1 & 9.2 & 12.0 & 85 & 60 & 86 & 77 & 225 & 98 \\
\hline Nov. & 6.6 & 6.5 & 5.3 & 4.6 & 8.4 & 6.0 & 34 & 54 & 20 & 39 & 65 & 44 \\
\hline Dec. & -2.8 & 1.8 & -2.4 & -3.6 & -2.6 & -1.5 & 23 & 64 & 48 & 59 & 44 & 41 \\
\hline Jan. & 2.7 & -2.2 & -3.3 & -5.0 & -6.8 & -2.9 & 54 & 21 & 20 & 0 & 43 & 30 \\
\hline Feb. & -1.1 & -4.8 & -4.0 & 0.3 & -5.5 & -1.8 & 2 & 68 & 99 & 42 & 23 & 49 \\
\hline Mar. & 5.6 & 9.2 & 4.0 & 6.1 & 5.9 & 5.2 & 72 & 124 & 78 & 132 & 53 & 68 \\
\hline Apr. & 14.5 & 10.0 & 10.0 & 10.6 & 14.9 & 12.5 & 62 & 106 & 116 & 121 & 146 & 109 \\
\hline May & 17.0 & 19.2 & 15.5 & 16.9 & 16.8 & 17.0 & 65 & 141 & 112 & 170 & 160 & 141 \\
\hline
\end{tabular}

from total weed densities and biomasses because a burndown herbicide is usually nonselective, and $>98 \%$ control was observed each year. An interaction for weed number between the main effects and years was observed for $\mathrm{N}$ sources $(P=$ $0.0152)$ and application timings $(P=0.0002)$. However, there was a significant $(P=0.0258)$ interaction between $\mathrm{N}$ sources and application timings for total winter annual weed biomass, and no significant 3 -way interaction (year $\times \mathrm{N}$ sources $\times$ application timings) was observed. For objective 2, henbit biomass main effects for fertilizer application timings $(P=0.0966)$ and $\mathrm{N}$ source/placement $(P=0.0146)$ were reported because no significant 2 - (application timing $\times \mathrm{N}$ source/placement) or 3-way (year $\times$ application timing $\times$ $\mathrm{N}$ source/placement) interactions were observed. However, individual years were reported due to a significant interaction $(P=0.0351)$ between $\mathrm{N}$ source/placement and years.

\section{Results and Discussion}

3.1. Nitrogen Sources and Application Timings. The total density of winter annual weeds differed depending on the year and environmental conditions (Table 2), which probably contributed to the 2-way interactions between years and application timings (Table 3 ) or $\mathrm{N}$ sources (Table 4). Prior to a burndown herbicide application, average density for all winter annual weed species was $15 \%$ greater for an early preplant $\mathrm{N}$ application compared to autumn application (Table 3). Only in 2006 weeds were more dense (34\%) for the early preplant $\mathrm{N}$ application compared to autumn application. The primary weed species in 2006 were small flower bittercress (Cardamine parviflora L.) (47\%), buttercup species (Ranunculus spp.) (22\%), Carolina foxtail (Alopecurus carolinianus Walt.) (20\%), and shepherd's purse (Capsella bursa-pastoris (L.) Medicus) (7\%). There was no difference in weed density between autumn or early preplant $\mathrm{N}$ applications in 2007, 2008, 2009, or 2010.

The $\mathrm{N}$ sources affected total winter annual weed density, which differed by year (Table 4) and was probably due to differences in the winter annual weed species present each year. Weed density was the lowest where anhydrous ammonia was applied in 2006 and 2007. In 2007, the primary weed species were purslane speedwell (Veronica peregrina L.) (83\%)
TABLE 3: Winter annual weed number in the spring following $\mathrm{N}$ application timings. Data were averaged over $\mathrm{N}$ sources.

\begin{tabular}{lcccccc}
\hline $\begin{array}{l}\text { N application } \\
\text { timing }\end{array}$ & 2006 & 2007 & 2008 & 2009 & 2010 & Average \\
\hline & 160 & 13 & 63 & 123 & 212 & 113 \\
$\begin{array}{l}\text { Autumn } \\
\begin{array}{l}\text { Early } \\
\text { preplant }\end{array}\end{array}$ & 242 & 12 & 88 & 156 & 167 & 133 \\
$\begin{array}{l}\text { LSD } \\
(P=0.1)\end{array}$ & 35 & NS & NS & NS & NS & 14 \\
\hline
\end{tabular}

and buttercup (13\%). Urea ammonium nitrate (UAN) had a weed density similar to anhydrous ammonia in 2006 and the lowest weed density in 2008. The lowest average weed density with UAN may have been due to necrosis and burn caused by the broadcast application of this $\mathrm{N}$ source (visual observation). High rates of UAN have caused visual injury to corn when broadcast was applied, which significantly reduced yield [29]. In 2008, the primary weed species were buttercup (67\%) and purslane speedwell (27\%), which may have been more susceptible to a UAN application because the primary species were broadleaf winter annuals. The autumn application was the earliest in 2008 compared to other years (Table 1), but the early preplant that year was similar to the other years. No significant differences in weed densities among $\mathrm{N}$ sources were observed in 2009 and 2010 (Table 4). In 2009 , the primary weed species were purslane speedwell (Veronica peregrina L.) (28\%), horseweed (Conyza canadensis (L.) Cronq) (21\%), small flower bittercress (16\%), buttercup (15\%), shepherd's purse (11\%), and Carolina foxtail (7\%). In 2010 , the primary weed species were purslane speedwell (61\%), small flower bittercress (13\%), field pennycress (Thlaspi arvense L.) (10\%), and buttercup (7\%). The overall weed density was the lowest where anhydrous ammonia was applied (averaged over years, 95 weeds $\mathrm{m}^{-2}$ ), which was similar to a broadcast application of UAN. This was probably due partially to the tillage from the anhydrous ammonia knife and injury from the UAN. In other research, soil $\mathrm{N}$ management affected annual weed seed germination which could affect seed mortality [18]. 
TABLE 4: Winter annual weed number in the spring following $\mathrm{N}$ application timings. Data were averaged over application timings.

\begin{tabular}{lcccccc}
\hline Nitrogen sources & 2006 & 2007 & 2008 & 2009 & 2010 & Average \\
\hline & & \multicolumn{2}{c}{ Weed number m } \\
32\% urea ammonium nitrate & 153 & 7 & 28 & 161 & 208 & 106 \\
Ammonium nitrate & 284 & 28 & 60 & 184 & 182 & 147 \\
Anhydrous ammonia & 123 & 1 & 95 & 89 & 171 & 95 \\
Polymer-coated urea & 204 & 14 & 74 & 142 & 201 \\
Nontreated control & 212 & 28 & 101 & 52 & 215 \\
Urea + NBPT (N-(n-butyl) thiophosphoric triamide) & 215 & 3 & 79 & 222 & 183 \\
Urea & 218 & 6 & 93 & 130 & 125 \\
LSD $(P=0.1)$ & 77 & 15 & 46 & NS & NS & 137 \\
\hline
\end{tabular}

Nitrogen application sources and timings affected winter annual weed biomass (Figure 1). Total winter annual weed biomass ranged from 45 to $155 \mathrm{~g} \mathrm{~m}^{-2}$, which was similar to results from a Kansas study that ranged from 47.5 to $172.7 \mathrm{~g} \mathrm{~m}^{-2}$ [4]. Weed biomass with UAN was $66 \%$ greater when applied early preplant compared to an autumn application. Applying UAN in autumn may have injured plants more than the other $\mathrm{N}$ sources, as mentioned above, and reduced plant density, which may have reduced biomass production (Table 3).

Winter annual weeds were smaller in autumn, while winter stress probably reduced overall biomass production compared to an early preplant application in spring. Ammonium nitrate and urea plus NBPT had greater winter annual weed biomasses compared to the nontreated control for both application timings, which was probably due to the readily available $\mathrm{N}$ with these $\mathrm{N}$ sources (Figure 1). Spring-applied anhydrous ammonia, polymer-coated urea, and nontreated urea had winter annual weed biomasses similar to the nontreated control. Since anhydrous ammonia was injected below the soil surface, $\mathrm{N}$ was probably not as readily available for winter annual weed uptake compared to the other $\mathrm{N}$ sources. In Canada, $\mathrm{N}$ fertilizer placement for wheat affected weed growth with a subsoil placement reducing the amount of $\mathrm{N}$ available to weeds which allowed greater $\mathrm{N}$ uptake by the wheat crop [24]. Moisture and temperature affect the release of $\mathrm{N}$ from polymer-coated urea [14, 30]. During 2006 and 2009 , in adjacent experiments in wheat [15] and corn [14], 20 to $80 \%$ of the urea was released by the time burndown herbicides were applied in this experiment. Broadcast surfaceapplied urea was probably readily available for uptake, though it could have experienced gaseous $\mathrm{N}$ loss and so reduced overall winter annual weed growth. This research indicates that winter annual weeds may yield greater biomasses from an autumn or early preplant $\mathrm{N}$ application, but this depends on the $\mathrm{N}$ source and the application timing for UAN. In this region, an autumn broadcast application of UAN or urea typically is associated with lower yields and so it is not recommended [14, 21]. Applying herbicide in autumn to control winter annual weeds could further limit corn yield losses [4].

3.2. Strip-Tillage, $N$ Application Timing, and $N$ Source. This site had a uniform stand of henbit (120 to 340 plants $\mathrm{m}^{-2}$ ) that varied in density depending on the year. There was a significant interaction between years and $\mathrm{N}$ source/placement $(P=0.0351)$ for henbit biomass in the spring prior to a burndown herbicide application. Autumn, winter, and spring precipitation and temperatures (Table 2) differed by year, which probably affected henbit growth. Dates for a burndown herbicide application included 24 April 2008, 4 May 2009, and 16 April 2010 (Table 1). Soybeans are typically harvested in mid- to late-October. It was relatively dry summer in 2007 [14], which probably affected soybean canopy development, and was followed by good autumn rainfall which allowed for good henbit growth and establishment. Overall precipitation was high in 2008 through 2010 as were overall corn grain yields [21].

Total winter annual weed biomass was $28 \%$ greater $(P=$ $0.0966)$ when applying $\mathrm{N}$ in autumn $\left(76 \mathrm{~g} \mathrm{~m}^{-2}\right)$ compared to an early preplant $\left(55 \mathrm{~g} \mathrm{~m}^{-2}\right)$ timing. This indicates that uncontrolled henbit in autumn utilized a significant amount of $\mathrm{N}$ from this application timing. This differs from results shown in Figure 1, where henbit was not present. By applying $\mathrm{N}$ closer to planting or after emergence, farmers could use fertilizer more efficiently and reduce immobilization of $\mathrm{N}$ by weed species. However, $\mathrm{N}$ used by winter annual weeds was not available for leaching loss, which could be significant with coarse-textured soils. Immobilization of $\mathrm{N}$ by cover crops and winter annual weeds has been known to occur [4]. The amount of $\mathrm{N}$ may also depend on the winter annual species, but this was not determined in this research. When $\mathrm{N}$ was applied usually after planting, $\mathrm{N}$ uptake by winter annual weeds ranged from 7 to $32 \mathrm{~kg} \mathrm{~N}$ ha $^{-1}$ by May [4]. At $\mathrm{N}$ rates similar to this research $\left(135 \mathrm{~kg} \mathrm{~N} \mathrm{ha}^{-1}\right)$, no difference in corn yields between herbicide application timings was observed [4]. This research indicated that a burndown herbicide was recommended prior to April; otherwise 16 to $17 \mathrm{~kg} \mathrm{~N}$ ha $^{-1}$ of additional $\mathrm{N}$ was recommended. In addition, $\mathrm{N}$ application timing could have affected germination and emergence since the effect of $\mathrm{N}$ is affected by weed species and environmental conditions [20].

Broadcasted urea or polymer-coated urea had greater winter annual biomass compared to a strip-till placement (Table 5). In the strip-till placement, tillage affected about $30 \%$ of the ground area (Figure 2), which reduced overall winter annual biomass in all treatments except the nontreated control. An autumn strip-tillage treatment also reduced winter annual weeds in cotton [31]. Our research indicates 
TABLE 5: Henbit biomass prior to a burndown herbicide application as affected by nitrogen fertilizer source and fertilizer placement in 2008, 2009, and 2010. Data were averaged over N application timings.

\begin{tabular}{|c|c|c|c|c|}
\hline Nitrogen source & 2008 & 2009 & 2010 & Average \\
\hline & \multicolumn{4}{|c|}{$\mathrm{g} \mathrm{m}^{-2}$} \\
\hline Anhydrous ammonia & 143 & 39 & 66 & 82 \\
\hline Anhydrous ammonia + nitrapyrin at $560 \mathrm{~g}_{\text {ai ha }}{ }^{-1}$ & 114 & 15 & 35 & 55 \\
\hline Polymer-coated urea broadcast & 275 & 24 & 33 & 109 \\
\hline Polymer-coated urea strip-till placement & 83 & 13 & 25 & 40 \\
\hline Nontreated & 117 & 4 & 31 & 51 \\
\hline Nontreated strip-tillage only & 107 & 18 & 21 & 49 \\
\hline Noncoated urea broadcast & 233 & 47 & 14 & 98 \\
\hline Noncoated urea strip-till placement & 87 & 28 & 13 & 42 \\
\hline $\operatorname{LSD}(P=0.1)$ & 108 & NS & NS & 38 \\
\hline
\end{tabular}

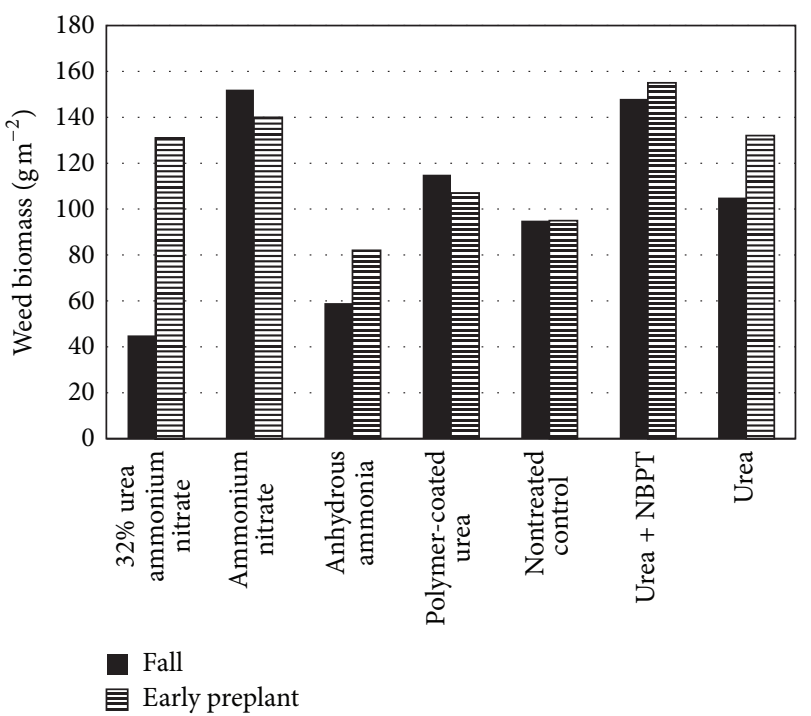

Figure 1: Total winter annual weed biomass as affected by $\mathrm{N}$ application sources and application timings. LSD $(P=0.05)$ was $45 \mathrm{~g} \mathrm{~m}^{-2}$. Data were averaged over years. NBPT, $\mathrm{N}$-(n-butyl) thiophosphoric triamide.

that $\mathrm{N}$ placement also reduced availability to shallow-rooting winter annual weeds such as henbit.

A combination of tillage that decreased growth along with placement of $\mathrm{N}$ away from the winter annual weeds reduced henbit biomass 57 to $63 \%$ when noncoated and polymercoated urea were strip-till applied compared to a broadcast surface $\mathrm{N}$ application of these $\mathrm{N}$ sources (Table 5). A reduction in henbit biomass may also help reduce soybean cyst nematode (Heterodera glycines) egg densities when rotating to a nonhost crop such as corn [32]. Placement of $\mathrm{N}$ was also important because the anhydrous ammonia treatments had henbit biomasses similar to the nontreated controls. Broadcast surface $\mathrm{N}$ is also susceptible to greater gaseous $\mathrm{N}$ loss than strip-till placement [30] and can increase henbit biomass production. Anhydrous ammonia in the absence of nitrapyrin had $40 \mathrm{~g} \mathrm{~m}^{-2}$ and $42 \mathrm{~g} \mathrm{~m}^{-2}$ greater henbit biomass than strip-till noncoated urea or polymer-coated urea, respectively. This indicated less $\mathrm{N}$ available for uptake and greater tillage with the Maverick unit compared to a single mole knife unit. However, henbit biomass was similar for the strip-till placement of PCU, noncoated urea, and anhydrous ammonia plus nitrapyrin, which is a nitrification inhibitor.

It was hypothesized that henbit growth would show a difference between broadcast PCU and noncoated urea due to PCU's slow-release properties [30]. Depending on the cropping system, differences in PCU release have been observed between surface and deep placements from April to May [14]. In 2009-2010, urea release was faster than previous years [30], which may have contributed to similarities between PCU and noncoated urea. Greater urea release (up to 20\%) was observed when PCU was surface applied compared to a striptill placement [14]. However, henbit biomass was the same between PCU and NCU (Table 5). This differed from a study in which broadcast PCU had a lower red clover (Trifolium pratense L.) cover crop biomass compared to broadcast NCU for an autumn $\mathrm{N}$ application, and red clover biomass was similar when PCU and NCU were applied early preplant [33]. These differences could be due to the shallow root system of henbit compared to a biennial red clover cover crop. Striptill placement of $\mathrm{N}$ fertilizer is recommended in order to minimize winter annual weed growth.

\section{Conclusion}

Greater total winter annual weed biomass resulted from an autumn or early preplant $\mathrm{N}$ application of certain $\mathrm{N}$ sources used for no-till corn production; this was probably due to the placement, availability of $\mathrm{N}$, and/or injury from the $\mathrm{N}$ source. Total winter annual weed density was also affected by $\mathrm{N}$ source, but it was inconsistent over the years evaluated here. Nitrogen source selection and application timing affects the impact of $\mathrm{N}$ on winter annual weeds and should be considered when recommending a burndown herbicide application timing. An autumn herbicide application should be considered when autumn $\mathrm{N}$ fertilizer is applied to the soil surface in a no-till corn production system.

Henbit biomass was $28 \%$ greater when applying $\mathrm{N}$ in autumn compared to an early preplant application timing. Nitrogen placement with strip-till placement helped reduce henbit biomass prior to a burndown herbicide application 


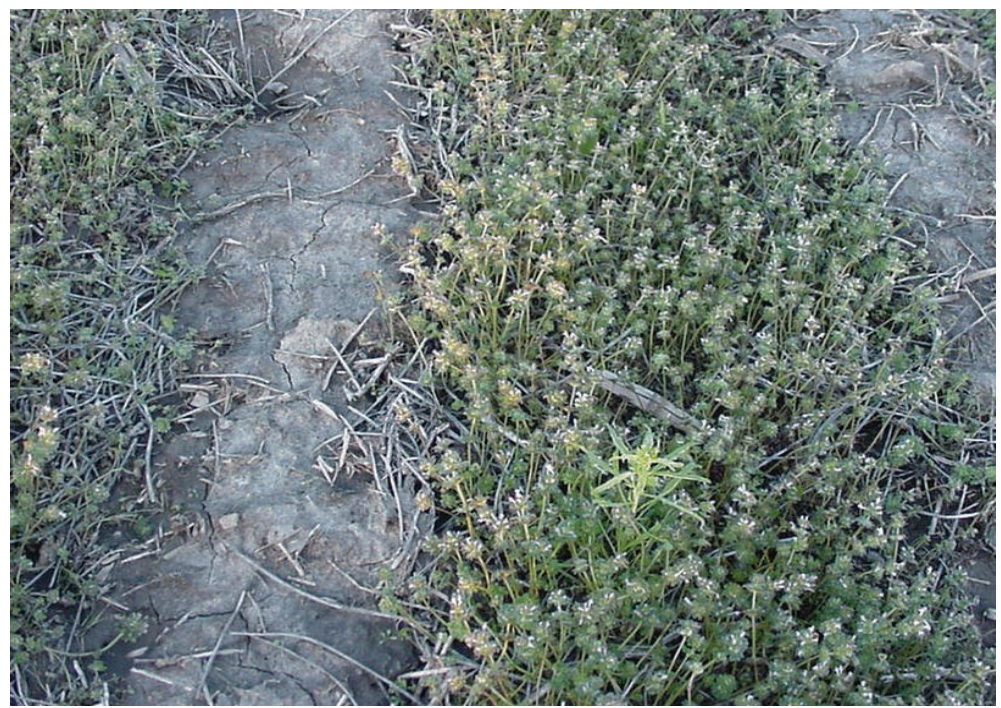

FIGURE 2: Henbit response to an early preplant strip-tillage (7 April 2008) treatment on 24 April 2008.

compared to a broadcast $\mathrm{N}$ application. Using strip-tillage $\mathrm{N}$ placement may also reduce interference associated with winter annual weeds, which may allow a delayed postemergence burndown application compared to a broadcast surface $\mathrm{N}$ application.

\section{Abbreviations}

NBPT: N-(n-butyl) thiophosphoric triamide.

\section{Nomenclature}

Ranunculus spp.:

Alopecurus carolinianus Walt.:

Zea mays L.:

Thlaspi arvense L.:

Lamium amplexicaule L.:

Conyza canadensis (L.) Cronq:

Veronica peregrina L.:

Capsella bursa-pastoris (L.) Medicus: Shepard's purse

Cardamine parviflora L.:
Buttercup species

Carolina foxtail

Corn

Field pennycress

Henbit

Horseweed

Purslane speedwell

bittercress.
Small flower

\section{Conflict of Interests}

The author declares that there is no conflict of interests regarding the publication of this paper.

\section{Acknowledgments}

The author would like to thank Patrick Nash, Randall Smoot, Chris Dudenhoeffer, and Clinton Meinhardt for their technical assistance with this research. A special thanks is extended to the Missouri Fertilizer and Ag Lime Board for their financial support.

\section{References}

[1] R. F. Krausz, B. G. Young, and J. L. Matthews, "Winter annual weed control with fall-applied corn (Zea mays) herbicides," Weed Technology, vol. 17, no. 3, pp. 516-520, 2003.

[2] K. D. Gibson, W. G. Johnson, and D. E. Hillger, "Farmer perceptions of problematic corn and soybean weeds in Indiana," Weed Technology, vol. 19, no. 4, pp. 1065-1070, 2005.

[3] N. Monnig and K. W. Bradley, "Influence of fall and early spring herbicide applications on winter and summer annual weed populations in no-till corn," Weed Technology, vol. 22, no. 1, pp. 42-48, 2008.

[4] N. D. Mueller, D. A. R. Diaz, J. D. Anita, D. E. Shoup, D. B. Mengel, and L. W. Murray, "Winter annual weed management and nitrogen rate effects on corn yield," Agronomy Journal, vol. 105, no. 4, pp. 1077-1086, 2013.

[5] R. E. Blackshaw, R. N. Brandt, H. H. Janzen, T. Entz, C. A. Grant, and D. A. Derksen, "Differential response of weed species to added nitrogen," Weed Science, vol. 51, no. 4, pp. 532-539, 2003.

[6] R. E. Blackshaw, L. J. Molnar, and H. H. Janzen, "Nitrogen fertilizer timing and application method affect weed growth and competition with spring wheat," Weed Science, vol. 52, no. 4, pp. 614-622, 2004.

[7] U. M. Sainju, B. P. Singh, W. F. Whitehead, and S. Wang, "Accumulation and crop uptake of soil mineral nitrogen as influenced by tillage, cover crops, and nitrogen fertilization," Agronomy Journal, vol. 99, no. 3, pp. 682-691, 2007.

[8] J. Mithila, C. J. Swanton, R. E. Blackshaw, R. J. Cathcart, and J. C. Hall, "Physiological basis for reduced glyphosate efficacy on weeds grown under low soil nitrogen," Weed Science, vol. 56, no. 1, pp. 12-17, 2008.

[9] M. G. Wagger, "Cover crop management and nitrogen rate in relation to growth and yield of no-till corn," Agronomy Journal, vol. 81, no. 3, pp. 533-538, 1989.

[10] V. M. Davis, G. R. Kruger, B. G. Young, and W. G. Johnson, "Fall and spring preplant herbicide applications influence spring emergence of glyphosate-resistant horseweed (Conyza canadensis)," Weed Technology, vol. 24, no. 1, pp. 11-19, 2010. 
[11] R. Werle, M. L. Bernards, T. J. Arkebauer, and J. L. Lindquist, "Environmental triggers of winter annual weed emergence in the Midwestern United States," Weed Science, vol. 62, no. 1, pp. 83-96, 2014.

[12] E. C. Hill, K. A. Renner, and C. L. Sprague, "Henbit (Lamium amplexicaule), common chickweed (Stellaria media), shepherd's-purse (Capsella bursa-pastoris), and field pennycress (Thlaspi arvense): fecundity, seed dispersal, dormancy, and emergence," Weed Science, vol. 62, no. 1, pp. 97-106, 2014.

[13] J. A. Stecker, D. D. Buchholz, R. G. Hanson, N. C. Wollenhaupt, and K. A. McVay, "Broadcast nitrogen sources for no-till continuous corn and corn following soybean," Agronomy Journal, vol. 85, no. 4, pp. 893-897, 1993.

[14] K. A. Nelson, P. P. Motavalli, and C. J. Dudenhoeffer, "Cropping system affects polymer-coated urea release and corn yield response in claypan soils," Journal of Agronomy and Crop Science, vol. 200, no. 1, pp. 54-65, 2014.

[15] P. R. Nash, P. P. Motavalli, and K. A. Nelson, "Nitrous oxide emissions from claypan soils due to nitrogen fertilizer source and tillage/fertilizer placement practices," Soil Science Society of America Journal, vol. 76, no. 3, pp. 983-993, 2012.

[16] A. S. Davis and M. Liebman, "Nitrogen source influences wild mustard growth and competitive effect on sweet corn," Weed Science, vol. 49, no. 4, pp. 558-566, 2001.

[17] K. V. Dhima and I. G. Eleftherohorinos, "Influence of nitrogen on competition between winter cereals and sterile oat," Weed Science, vol. 49, no. 1, pp. 77-82, 2001.

[18] A. S. Davis, "Nitrogen fertilizer and crop residue effects on seed mortality and germination of eight annual weed species," Weed Science, vol. 55, no. 2, pp. 123-128, 2007.

[19] R. E. Blackshaw and R. N. Brandt, "Nitrogen fertilizer rate effects on weed competitiveness is species dependent," Weed Science, vol. 56, no. 5, pp. 743-747, 2008.

[20] A. E. Sweeney, K. A. Renner, C. Laboski, and A. Davis, "Effect of fertilizer nitrogen on weed emergence and growth," Weed Science, vol. 56, no. 5, pp. 714-721, 2008.

[21] K. A. Nelson, P. R. Nash, and C. J. Dudenhoeffer, "Effect of nitrogen source and weed management systems on no-till corn yields," Journal of Agricultural Science, vol. 5, no. 8, pp. 87-96, 2013.

[22] S. P. Evans, S. Z. Knezevic, J. L. Lindquist, and C. A. Shapiro, "Influence of nitrogen and duration of weed interference on corn growth and development," Weed Science, vol. 51, no. 4, pp. 546-556, 2003.

[23] S. P. Evans, S. Z. Knezevic, J. L. Lindquist, C. A. Shapiro, and E. E. Blankenship, "Nitrogen application influences the critical period for weed control in corn," Weed Science, vol. 51, no. 3, pp. 408-417, 2003.

[24] R. E. Blackshaw, G. Semach, and H. H. Janzen, "Fertilizer application method affects nitrogen uptake in weeds and wheat," Weed Science, vol. 50, no. 5, pp. 634-641, 2002.

[25] K. A. O’Reilly, J. D. Lauzon, R. J. Vyn, and L. L. Van Eerd, "Nitrogen cycling, profit margins and sweet corn yield under fall cover crop systems," Canadian Journal of Soil Science, vol. 92, no. 2, pp. 353-365, 2012.

[26] O. B. Hesterman, M. P. Russelle, C. C. Sheaffer, and G. H. Heichel, "Nitrogen utilization from fertilizer and legume residues in legume-corn rotations," Agronomy Journal, vol. 79, no. 4, pp. 726-731, 1987.

[27] Z. Dou, R. H. Fox, and J. D. Toth, "Tillage effect on seasonal nitrogen availability in corn supplied with legume green manures," Plant and Soil, vol. 162, no. 2, pp. 203-210, 1994.
[28] SAS Institute, SAS User's Guide, Version 9.1.2, SAS Institute, Cary, NC, USA, 2010.

[29] C. D. Foy, G. Montenegro, and S. A. Barber, "Foliar feeding of corn with urea nitrogen," Soil Science Society of America Journal, vol. 17, no. 4, pp. 387-390, 1953.

[30] P. R. Nash, K. A. Nelson, and P. P. Motavalli, "Polymer-coated urea application ratios and timings affect wheat and doublecrop soybean yields," Agronomy Journal, vol. 104, pp. 1074-1084, 2012.

[31] T. M. Webster, "Effect of autumn management on winter annual weeds prior to cotton planting," Journal of Cotton Science, vol. 14, no. 2, pp. 113-118, 2010.

[32] R. Werle, M. L. Bernards, L. J. Giesler, and J. L. Lindquist, "Influence of two herbicides on soybean cyst nematode (Heterodera glycines) reproduction on henbit (Lamium amplexicaule) roots," Weed Technology, vol. 27, no. 1, pp. 41-46, 2013.

[33] P. R. Nash, K. A. Nelson, and P. P. Motavalli, "Corn yield response to polymer and non-coated urea placement and timings," International Journal of Plant Production, vol. 7, no. 3 , pp. 373-392, 2013. 


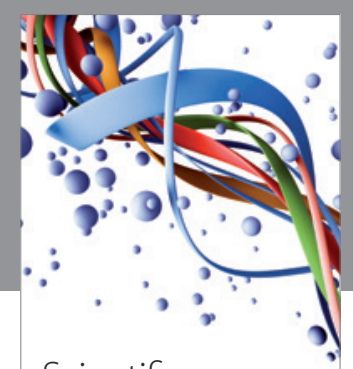

Scientifica
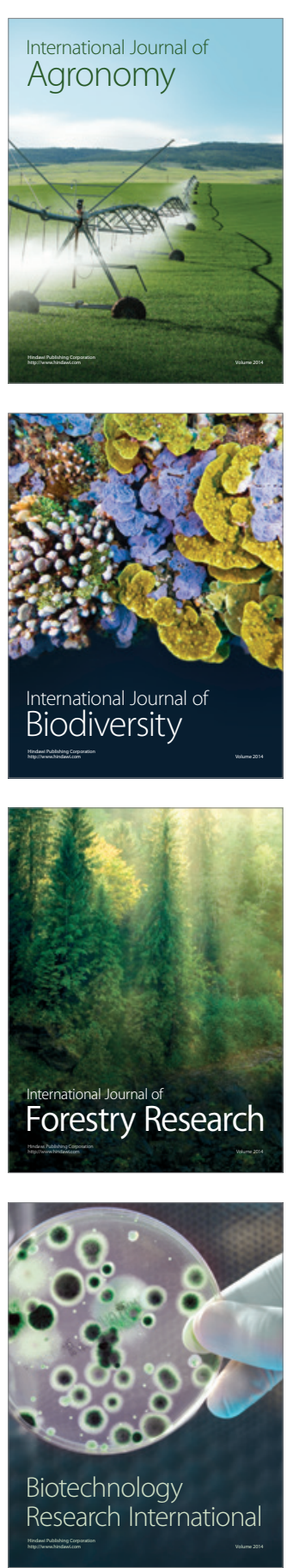
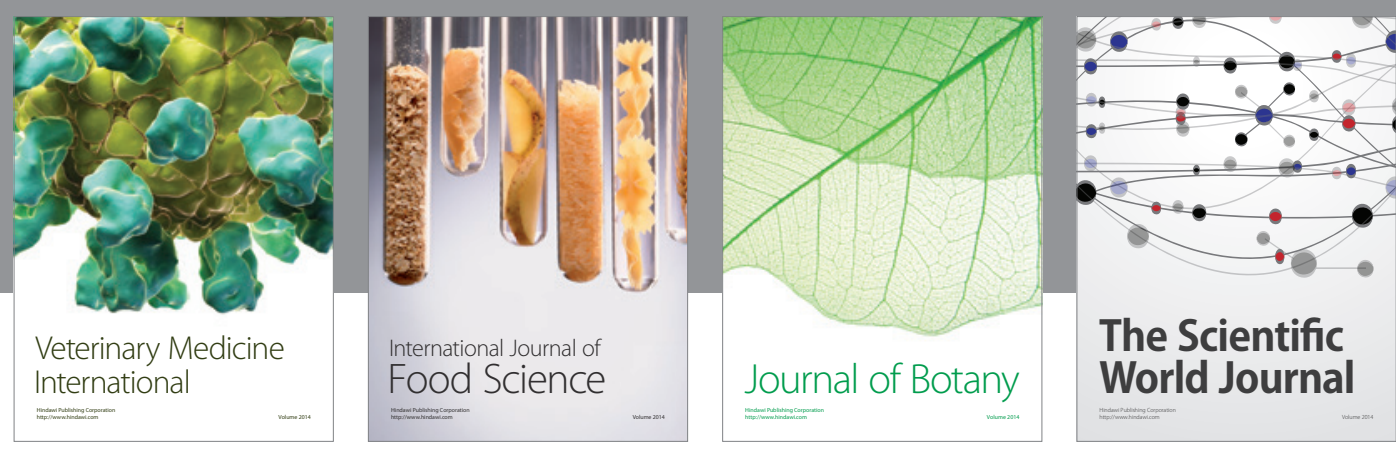

The Scientific World Journal
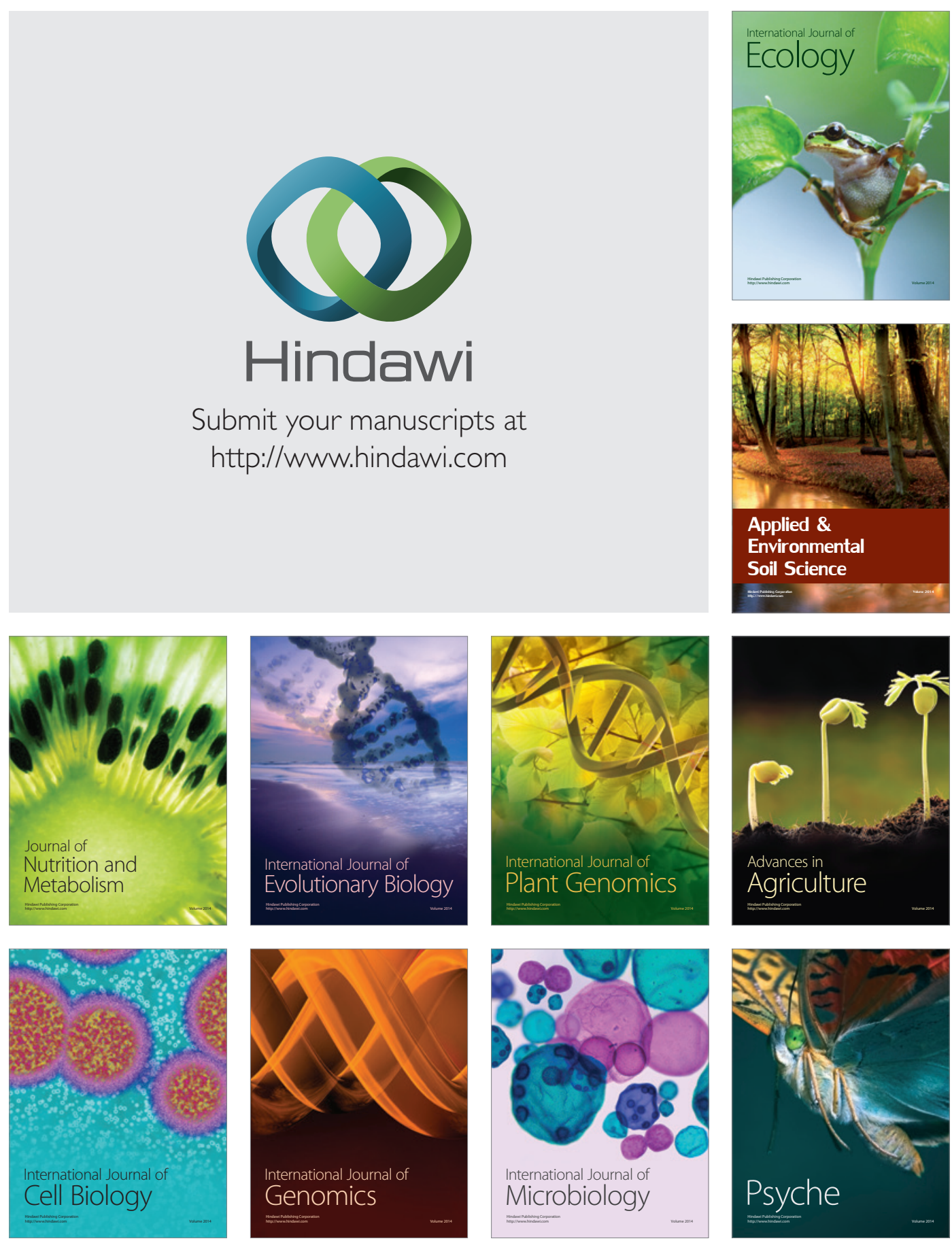